\title{
Impact of COVID-19 on Children and Adults: A Bibliometric Assessment of Global Publications
}

\author{
BM Gupta ${ }^{1}$, M Surulinathi ${ }^{2}$, Ghouse Modin Nabeesab Mamdapur ${ }^{3,{ }^{*}}$, Jivesh Bansal ${ }^{4}$, Madhu Bansal ${ }^{4}$
}

\section{BM Gupta' ${ }^{1}$ M Surulinathi' ${ }^{2}$, Ghouse Modin Nabeesab Mamdapur ${ }^{3, *}$, Jivesh Bansal ${ }^{4}$, Madhu Bansal ${ }^{4}$}

${ }^{1}$ Formerly with CSIR-NISTADS, New Delhi, INDIA.

${ }^{2}$ Department of Library and Information

Science, Bharathidasan University,

Tiruchirappalli, Tamil Nadu, INDIA.

${ }^{3}$ Synthite Industries $(P) L t d$, Kolenchery,

Kerala, INDIA.

${ }^{4}$ Panjab University, Central Library,

Chandigarh, INDIA.

\section{Correspondence}

Mr. Ghouse Modin Nabeesab

Mamdapur

Synthite Industries (P) Ltd, Kolenchery,

Kerala, 682311, INDIA.

Phone no: +91 0484-2889070

Email: ghouse@synthite.com

History

- Submission Date: 15-03-2021

- Revised Date: 01-05-2021

- Accepted Date: 16-07-2021

DOI : 10.5530/ijmedph.2021.3.25

Article Available online

http://www.ijmedph.org/v11/i3

\section{Copyright}

(C) 2021 Phcog.Net. This is an openaccess article distributed under the terms of the Creative Commons Attribution 4.0 International license.

\begin{abstract}
The paper presents a analysis of quantitative and qualitative dimensions of global research output (3488 records) on "Impact of COVID-19 on Children and Adolescents", based on indexed publications in Scopus database. The global publications on this theme averaged 8.31 citations per paper. About $1.49 \%$ share of its total publications in this area received external funding support. The 145 countries partcipitated in global research output on "Impact of COVID-19 on Children and Adults", of which the top 10 countries accounted for $85.21 \%$ and more than $100 \%$ share of global publications and citations. The USA, U.K. and Italy leads in global publications ranking and productivity as against China (3.16), U.K (1.28) and USA (1.27) leading in terms of relative of relative citation index. The 412 organizations and 661 authors participated in global research on this theme, with top 15 most productive organizations and authors contributing $21.07 \%$ and $4.30 \%$ global publications share and $38.05 \%$ and $12.98 \%$ global citations share. Harvard Medical School, USA, Huazhong University of Science and Technology, China and Tongji Medical College, China leads the world as the most productive organizatons (with 480,67 and 63 publications) and Huazhong University of Science and Technology, China (31.97 and 3.85), Tongji Medical College, China (19.92 and 2.40) and Children Hospital of Philadelphia, USA (19.30 and 2.32) leading as the most impactful organizations in the world in terms of citation per paper and relative citation index. D. Buonsensov, C.Calvo and X. Lu were the most productive authors (with 15, 12 and 12 papers) and X.Lu (103.83 and 12.49), A. Licari ( 40.11 and 4.83) and G.L. Marseglia( 34.09 and 4.1) were the most impactful authors. JAMA Pediatrics, Pediatrics Infectious Disease Journal and Acta Paediatrica International Journal of Pediatrics were the most productive journals (with 71, 60 and 58 papers) and Pediatrics (36.59, JAMA Pediatrics (19.49) and Acta Paediatrica International Journal of Pediatrics (14.93) were the most impactful journals.

Key words: COVID-19, Impact, Children, Adolescents, Global, Publications, Scientometrics, Bibliometrics.
\end{abstract}

\section{INTRODUCTION}

Coronavirus disease 19 (COVID-19), originated at Wuhan city of China in early December 2019 has rapidly widespread with confirmed cases in almost every country across the world and has become a new global public health crisis. The etiological agent was designated as Severe acute respiratory syndrome coronavirus 2 (SARS-CoV-2). The virus was originated in bats and human transmission primarily occurs through direct, indirect, or close contact with infected people through infected secretions such as respiratory secretions, saliva or through respiratory droplets that are expelled when an infected person coughs, sneezes, or speaks. The World Health Organization coined the term COVID-19 and declared this novel coronavirus disease as a pandemic on March 11, 2020. The virus infects the human respiratory epithelial cells by binding through Angiotensin-Converting Enzyme 2 (ACE2) receptors. The major clinical symptoms of the disease are fever, non-productive cough, fatigue, malaise and breathlessness. Severe illness such as pneumonia, acute respiratory distress syndrome
(ARDS), and death occurs in the elderly and patients with comorbid conditions. ${ }^{1}$ Globally, as 15 May 2021, there have been $161,513,458$ confirmed cases of COVID-19, including 3,352,109 deaths, reported to WHO from 213 countries and territories. ${ }^{2}$

There are more than 2.2 billion children in the world who constitute approximately $28 \%$ of the world's population. Those aged between 10 to 19 years make up $16 \%$ of the world's population (UNICEF, 2019). Of all COVID-19 cases reported worldwide last year, children under 18 years accounted for about $8 \%$, despite comprising $29 \%$ of the global population, according to the World Health Organization. ${ }^{3}$ Children of all ages can get COVID-19. Children, particularly those younger than 12 to 14 years of age, appear to be affected less commonly than adults, although children typically have a lower risk of exposure than adults and are tested less frequently than adults. In surveillance from various countries children typically account for up to 15 percent of laboratory-confirmed cases. ${ }^{4}$ To date, data on COVID-19 in children and 
adolescents remain scarce, despite the number of confirmed COVID-19 cases now exceeding 8 million globally. Nevertheless, a small proportion of children and adolescents develop severe disease and require ICU support, frequently needing prolonged ventilatory support. However, fatal outcome is rare overall. ${ }^{5}$

The unexpected disruption of the social fabric and norms has affected the behavioral and mental health of the public, including children. The mental health of children has been influenced by several ways, as this unprecedented situation changed a way they typically grow, learn, play, behave, interact, and manage emotions. Children with pre-existing psychiatric disorders such as attention-deficit/hyperactivity disorder (ADHD), anxiety, depression, mood disorders, and behavior disorders could be adversely impacted during this stressful situation. ${ }^{6}$

The COVID-19 pandemic is harming health, social and material well-being of children worldwide, with the poorest children, including homeless children and children in detention, hit hardest. School closures, social distancing and confinement increase the risk of poor nutrition among children, their exposure to domestic violence, increase their anxiety and stress, and reduce access to vital family and care services. Widespread digitalisation mitigates the education loss caused by school-closures, but the poorest children are least likely to live in good home-learning environments with internet connection. Furthermore, increased unsupervised on-line internet use has magnified issues around sexual exploitation and cyber-bullying. ${ }^{\text {? }}$

COVID-19 affects all components of the respiratory system, including the neuromuscular breathing apparatus, the conducting airways, the respiratory airways and alveoli, the pulmonary vascular endothelium, and pulmonary blood flow. Viral pneumonia is the most frequent serious clinical manifestation of COVID-19, prominently featuring fever, cough, dyspnea, hypoxemia, and bilateral infiltrates on chest radiography. Dry cough is more common than a productive cough. Dyspnea appears after a median time of 5 to 8 days. Severe hypoxemic respiratory failure consistent with the Berlin definition of the acute respiratory distress syndrome (ARDS) occurs in a significant proportion of patients with COVID-19 pneumonia.. While the pulmonary system is most commonly affected, extrapulmonary clinical manifestations of COVID-19 exist and affect multiple other organs and organ systems including cardiovascular, renal, hepatic, gastrointestinal, ocular, dermatologic, and neurological systems, which could have significant health consequences. ${ }^{8,9}$

Bibliometrics, together with novel visualization methods of scientific information, have been used here which is helpful in identifing emerging outbreaks of infectious disease. Bibliometrics is also recognized as an essential tool and is widely used in a variety of fields to measure and evaluate scientific research quantitatively and qualitatively. ${ }^{10}$

\section{Literature Review}

Athough several bibliometric studies have been recently carried output on global and national output of Coronovirus research as well as on COVID-19. One recent study was undertaken by Monzani, Tagliaferri, Bellone, Genoni and Rabbone, ${ }^{11}$ which analysed 2301 global publications on COVID-19 in pediatric age using data from Scopus database during January 1, 2020 and June 11, 2020. A bibliometric methodology was applied to evaluate the total number of papers and citations, journal and publication types, the top-productive institutions and countries and their scientific collaboration, the core keywords. Grover, Gupta amd Mamdapur ${ }^{12}$ carried out another bibliometric study on the "Impact of COVID-19 on Mental Health of Children and Adolescents, which studied 1787 global papers indexed in Scopus database duting 2020-21.

Since no recent comprensive study was available on this topic, we decided to undertake the present study on the "Impact of COVID-19 on Children and Adults" using bibliometric methods to understand bibliometric characterstics of global literature and to study the research trends. It also evaluates the performance of global countries, organizations, authors and journals, besides identifying the scatter of literature across broad subjects and keywords for understanding the research trends. The study used indexed publications data till 1 May 2021 from Scopus databases

\section{MATERIALS AND METHODS}

For this study, the global publications on the "Impact of COVID-19 on Children and Adolescents" were identified, retrievied and downloaded from the the Scopus database (http://www.scopus.com) on 1.5..2021 using a well conceived search strategy. Here a set of two types keywords related to "COVID-19" and "Children or Adolescents" were used in "Keyword tag" and in "Article Title tag" (joined by Bolean operator "OR") of the Scopus database, yielding 3488 global records. The search strategy was further refined first by country to get publication output data of top 10 countries and secondly to get statistics on global output by subject, collaborating country, organization, author and journal. Citations to publications were counted from date of their publication till 1.5.2021.

TITLE ( "COVID 19" OR "2019 novel coronavirus" OR "coronavirus 2019” OR “coronavirus disease 2019” OR “2019-novel CoV” OR “2019 ncov" OR covid 2019 OR covid19 OR "corona virus 2019” OR ncov2019 OR ncov2019 OR “nCoV 2019” OR 2019-ncov OR covid-19 OR "Severe acute respiratory syndrome coronavirus 2" OR "SARS-CoV-2" ) OR KEY ( "COVID 19" OR "2019 novel coronavirus" OR "coronavirus 2019” OR “coronavirus disease 2019” OR “2019-novel CoV” OR “2019 ncov" OR covid 2019 OR covid19 OR “corona virus 2019” OR ncov2019 OR ncov2019 OR “nCoV 2019” OR 2019-ncov OR covid-19 OR "Severe acute respiratory syndrome coronavirus 2" OR "SARS-CoV-2" ) and TITLE (CHILD^ OR INFANT OR ADOLESCENT)

\section{ANALYSIS AND RESULTS}

\section{Publication Growth}

The global publications on "Impact of COVID 19 on Children and Adults" consisted of 3488 records $(2021=2157 ; 2021=1331)$ as indexed in Scopus database during 2020 -2021. The 3488 global publications on this theme received 28972 citations and averaged 8.31 citations per paper (CPP). Only 52 (1.49\%) out of 1797 global publications in this area were funded by national and international funding agencies. These 52 funded papers received 13345 citations, averaging 256.63 citations per paper. The major agencies providing funding support to global research in this area were U.S.Department of Health and Human Service (127 papers), National Institute of Health, USA (117 papers), National Natural Science Foundation of China (54 papers), National Institute of Health Research (32 papers), European Commission (27 papers), National Institute of Mental Health (21 papers), Center for Disease Control and Prevention, USA (18 papers), U.K. Research and Innovation (18 papers), etc.

The 59.09\% (2061) and $15.63 \%$ (545) share of global publications appeared as articles and letters, followed by reviews, notes and editorials (9.98\%, 7.94\% and 5.42\%), short surveys, eerratum and conference papers $(0.83 \%, 0.75 \%$ and 0.34$)$ and data paper $(0.03 \%)$.

\section{Top Ten Most Productive Countries}

The 145 countries took part in global research on "Impact of COVID-19 on Children and Adolescents" and their distribution was uneven: 93 countries published 1-10 papers, 36 countries published 11-50 papers, 4 countries published 51-100 papers and 12 countries published 104-941 papers each. The top 10 most countries among 145 partcipitating countries, contributed 117 to 941 papers and together contributed $85.21 \%$ share of global publications outout and more than $100 \%$ share 
to global citation output.. USA, U.K., Italy and China are the top ranking countries with global publication share of $26.98 \%, 11.41 \%$ and $10.92 \%$ respectively, followed by India (6.34\%), Canada, Spain, Turkey, Australia and France (from 3.35\% to 4.96\%). China (3.16), U.K (1.28), USA (1.27), France (1.22), Italy (1.15) and Australia (1.08) registered relative citation index above 1.0 The share of international collaborative papers in global output of the top 10 countries varied from $13.60 \%$ to $61.29 \%$, with average value as $33.48 \%$ during $2020-21$ (Table 1 ).

\section{Collaboration among Top 10 countries}

All the top 10 countries have had one to many collaborative linkages and their total collaborative linkages varied from 54 to 295. Their individual country to country collaborative linkages varied from 1 to 63 . The top countries with most collaborative linkages (295, 269 and 155) were -- USA, U.K. and Italy. The three countries with least collaborative linkages (54, 94 and 114) were -- China, India and France. The research collaboration at country-country level was the most between USA-Canada (63 linkages), followed by USA - U.K. (59 linkages), USA-Canada (41 linkages), U.K. - Italy (37 linkages), USA-China (37 linkages), usa-Italy (34 linkages), U.K.-Spain (31 linkages), U.K. - Spain (28 linkages), etc. (Table 2).

\section{Subject-Wise Distribution of Global Research Output}

Among 9 broad subjects (as identified in Scopus database) contributing to research on "Impact of COVID-19 on Children and Adolescents', Medicine contributed the largest publication share (83.89\%) to global output, followed by Psychology (10.24\%), Social sciences (7.68\%), and other five subjects contributing less than $5.0 \%$ (from $1.58 \%$ to $4.90 \%$ ). Environment Science registered the largest citation impact per paper (10.81) and least by Pharmacology, Toxicology and Pharmaceutics (4.47) (Table 3).

\section{Sub-Field Wise Distribution of Papers}

Mental health and related disorders accounted for the largest publications share (51.55\%) of global publications on "The Impact of COVID-19 on Children and Adolescents", followed by respiratory related disorders (17.06\%) and the rest are on extra-pulmonary manifestions of COVID-19

\begin{tabular}{|c|c|c|c|c|c|c|c|c|c|}
\hline S.No & $\begin{array}{l}\text { Name } \\
\text { of the } \\
\text { Country }\end{array}$ & TP & TC & CPP & $\% \mathrm{TP}$ & HI & ICP & $\% I C P$ & $\mathrm{RCl}$ \\
\hline 1 & USA & 941 & 9904 & 10.52 & 26.98 & 44 & 259 & 27.52 & 1.27 \\
\hline 2 & U.K & 398 & 4236 & 10.64 & 11.41 & 33 & 188 & 47.24 & 1.28 \\
\hline 3 & Italy & 381 & 3647 & 9.57 & 10.92 & 31 & 109 & 28.61 & 1.15 \\
\hline 4 & China & 336 & 8823 & 26.26 & 9.63 & 40 & 85 & 25.30 & 3.16 \\
\hline 5 & India & 221 & 634 & 2.87 & 6.34 & 12 & 52 & 23.53 & 0.35 \\
\hline 6 & Canada & 173 & 1166 & 6.74 & 4.96 & 18 & 99 & 57.23 & 0.81 \\
\hline 7 & Spain & 156 & 1133 & 7.26 & 4.47 & 15 & 57 & 36.54 & 0.87 \\
\hline 8 & Turkey & 125 & 343 & 2.74 & 3.58 & 10 & 17 & 13.60 & 0.33 \\
\hline 9 & Australia & 124 & 1110 & 8.95 & 3.56 & 12 & 76 & 61.29 & 1.08 \\
\hline \multirow[t]{3}{*}{10} & France & 117 & 1186 & 10.14 & 3.35 & 15 & 53 & 45.30 & 1.22 \\
\hline & Total & 2972 & 32182 & 10.83 & 85.21 & 23 & 995 & 33.48 & 1.30 \\
\hline & World & 3488 & 28972 & 8.31 & & & & & \\
\hline
\end{tabular}

$\mathrm{TP}=$ Total Papers; $\mathrm{TC}=$ Total Citations; $\mathrm{CPP}=$ Citations PerPaper; $\mathrm{ICP}=$ International Collaborative Papers; HI $h$-Index; RCI=Relative Citation Index

\begin{tabular}{|c|c|c|c|}
\hline S.No & $\begin{array}{l}\text { Name of the } \\
\text { Country }\end{array}$ & $\begin{array}{c}\text { Number of Collaborative linkages } \\
\text { with other } 9 \text { countries }\end{array}$ & $\begin{array}{c}\mathrm{TCL} \\
\text { (NOC) }\end{array}$ \\
\hline 1 & USA & $\begin{array}{c}\text { 2(59), 3(34), 4(37), 5(20), 6(63), 7(18), } \\
8(9), 9(31), 10(24)\end{array}$ & $295(9)$ \\
\hline 2 & U.K & $\begin{array}{c}\text { 1(59), 3(39), 4(24), 5(23), 6(27), 7(31), } \\
8(11), 9(31), 10(24)\end{array}$ & $269(9)$ \\
\hline 3 & Italy & $\begin{array}{c}\text { 1(34), 2(39), 4(6), 5(8), 6(6), 7(25), 8(10), } \\
9(8), 10(19)\end{array}$ & $155(9)$ \\
\hline 4 & China & $\begin{array}{c}\text { 1(37), 2(24), } 3(6), 5(5), 6(4), 7(3), 8(1), \\
9(9), 10(5)\end{array}$ & $94(9)$ \\
\hline 5 & India & $\begin{array}{c}\text { 1(20), 2(23), } 3(8), 4(5), 6(7), 7(6), 8(4), \\
9(11), 10(10)\end{array}$ & $94(9)$ \\
\hline 6 & Canada & $\begin{array}{c}\text { 1(63), 2(27), } 3(6), 4(4), 5(7), 7(7), 8(3), \\
9(14), 10(7)\end{array}$ & $138(9)$ \\
\hline 7 & Spain & $\begin{array}{c}\text { 1(18), 2(31), } 3(25), 4(3), 5(6), 6(7), 8(7) \\
9(5), 10(13)\end{array}$ & $115(9)$ \\
\hline 8 & Turkey & $\begin{array}{c}1(9), 2(11,3(10), 4(1), 5(4), 6(3), 7(7), \\
9(3), 10(6)\end{array}$ & $54(9)$ \\
\hline 9 & Australia & $\begin{array}{c}\text { 1(31), 2(31), 3(8), 4(9), 5(11), 6(14), 7(5), } \\
8(3), 10(6)\end{array}$ & $118(9)$ \\
\hline 10 & France & $\begin{array}{c}1(24), 2(24,3(19), 4(5), 5(10), 6(7), \\
7(13), 8(6), 9(6)\end{array}$ & $114(9)$ \\
\hline
\end{tabular}

$\mathrm{TCL}=$ Total Collaborative linkages; NOC=Number of countries

Table 3: Subject-Wise Breakup of Indian Publications in "Impact of COVID-19 on Children's and Adults" during 2020-21.

\begin{tabular}{|c|c|c|c|c|c|}
\hline S.No & Subject & TP & TC & CPP & \%TP \\
\hline 1 & Medicine & 2926 & 27364 & 9.35 & 83.89 \\
\hline 2 & Psychology & 357 & 2030 & 5.69 & 10.24 \\
\hline 3 & Social Sciences & 268 & 1165 & 4.35 & 7.68 \\
\hline 4 & $\begin{array}{l}\text { Immunology and } \\
\text { MIcrobiology }\end{array}$ & 171 & 1849 & 10.81 & 4.90 \\
\hline 5 & Nursing & 165 & 932 & 5.65 & 4.73 \\
\hline 6 & $\begin{array}{l}\text { Biochemistry, Genetics and } \\
\text { Molecular Biology }\end{array}$ & 155 & 1216 & 7.85 & 4.44 \\
\hline 7 & Neurosciences & 94 & 485 & 5.16 & 2.69 \\
\hline 8 & Environment Science & 89 & 973 & 10.93 & 2.55 \\
\hline 9 & $\begin{array}{l}\text { Pharmacology, Toxicology } \\
\text { and Pharmaceutics }\end{array}$ & 55 & 246 & 4.47 & 1.58 \\
\hline & Global output & 3488 & 28972 & 8.31 & \\
\hline
\end{tabular}

$\mathrm{TP}=$ Total Papers; $\mathrm{TC}=$ Total Citations; $\mathrm{CPP}=$ Citations Per Paper

disease. Amonst extra-pulmonary manifestations, Cardiovascular related disorders accounts for the highest share (11.47\%), followed by Systematic Inflammatory Response Syndrome (10.84\%), Multisystem Inflammatory Syndrome (7.40\%), Mucocutaneous Lymph Node Syndrome (\&.08\%), Diabetes related endocrine disorders (4.90\%), etc. (Table 4$)$.

\section{Top 15 Most Productive Organizations}

In all 412 organizations participated in global research on "Impact of COVID-19 on Children and Adolescents", of which 251 organizations published 1-10 papers each, 141 organizations published 11-30 papers 


\begin{tabular}{|c|c|c|c|c|c|}
\hline \multicolumn{6}{|c|}{$\begin{array}{l}\text { Table 4: Distribution of Publications on Impact of COVID } 19 \text { on } \\
\text { Children's and Adolescents by Type of Disease. }\end{array}$} \\
\hline S.No & Name of the Disease* & TP & TC & CPP & $\% T P$ \\
\hline 1 & $\begin{array}{l}\text { Mental Health and Related } \\
\text { Psychiatric Disorders }\end{array}$ & 1798 & 20511 & 11.41 & 51.55 \\
\hline 2 & Respiratory Related Disorders & 595 & 14136 & 23.76 & 17.06 \\
\hline 3 & \multicolumn{5}{|l|}{ Extra Pulmonary Manifestations } \\
\hline 3.1 & $\begin{array}{l}\text { Cardiovascular Disease and } \\
\text { Related Disorders }\end{array}$ & 400 & 4782 & 11.96 & 11.47 \\
\hline 3.2 & $\begin{array}{l}\text { Systematic Inflammatory } \\
\text { Response Syndrome }\end{array}$ & 378 & 4220 & 11.16 & 10.84 \\
\hline 3.3 & $\begin{array}{l}\text { Multisystem Inflammatory } \\
\text { Syndrome }\end{array}$ & 258 & 2201 & 8.53 & 7.40 \\
\hline 3.4 & $\begin{array}{c}\text { Mucocutaneous Lymph Node } \\
\text { Syndrome }\end{array}$ & 247 & 4248 & 17.20 & 7.08 \\
\hline 3.5 & $\begin{array}{c}\text { Diabetes and Related Endocrine } \\
\text { Disorders }\end{array}$ & 171 & 1753 & 10.25 & 4.90 \\
\hline 3.6 & Gastro Related Diseases & 89 & 2372 & 26.65 & 2.55 \\
\hline 3.7 & Skin Related Diseases & 62 & 880 & 14.19 & 1.78 \\
\hline 3.8 & Kawakasi Disease & 59 & 403 & 6.83 & 1.69 \\
\hline 3.9 & Eye Disease-Conjunctivitis & 53 & 1523 & 28.74 & 1.52 \\
\hline \multirow[t]{3}{*}{3.10} & Neurological Diseases & 37 & 381 & 10.30 & 1.06 \\
\hline & Renal & 17 & 64 & 3.76 & 0.49 \\
\hline & Global total & 3488 & & & \\
\hline
\end{tabular}

There is dublication and overlapping of publications across subjects

each, 15 organizations $31-52$ papers each and 5 organizations $51-80$ papers each. The productivity of top 15 most productive organizations varied from 33 to 80 publications per organization; together they contributed $21.07 \%$ (735) global publications share and 38.05\% (11025) global citations share. Their detailed scientometric profile of top 15 most productive organizations is presented in Table 5.

- $\quad$ Five organizations registered their publications output above their group average (49.0): Harvard Medical School, USA (80 papers), Huazhong University of Science and Technology, China (67 papers), Tongji Medical College, China (63 papers), Children Hospital, Boston, USA (61 papers) and IRCCS Ospedale Pediatrico Bambino Gesu, Italy (53 papers);

- Six organizations registered their citations per paper and relative citation index above the group average (15.0 and 1.81) of all organizations: Huazhong University of Science and Technology, China (31.97 and 3.85), Tongji Medical College, China (19.92 and 2.40), Childrens Hospital of Philadelphia, USA (19.30 and 2.32), INSERM, France (17.54 and 2.11), University of Melbourne, Australia (16.70 and 2.01) and Children Hospital, Boston, USA (16.34 and 1.97).

\section{Institutional Collaboration among Top 15 Most Productive Organizations}

The total collaborative linkages of top 15 organizations varied from 6 to 79 . The individual organization to organization collaborative linkages varied from 1 to 62 . Amongst top 15 most productive organizations, the top 3 organizations with largest linkages (79, 71 and 69) were Children Hospital, Boston, USA, Huazhong University OF Science and Technology, China and Harvard Medical School, USA. The top 3 organizations with least linkages (3, 6 and 12) were: INSERM, France, Universita degli Studi di
Milano, Italy and Sapienza University of Rome, Italy. In terns of organization to organization linkages, the largest number of collaborative linkages (62) are between Huazhong University oF Science and Technology, China and Tongji Medical College, China, followed by Harvard Medical School, USA and Children Hospital, Boston, USA (46 linkages), Hospital for Sick Children University of Toronto, Canada and University of Toronto, Canada (22 linkages), Children Hospital, Boston, USA and Hospital for Sick Children University of Toronto, Canada (!0 linkages), etc (Table 6).

\section{Top 15 Most Productive Authors}

661 authors participated in global research on "Impact of COVID19 on Children and Adolescents", of which 583 authors published 1-5 paper each, 72 authors 6-10 papers each and 6 authors 11-5 papers each. The research productivity of top 15 most productive authors varied from 8 to 15 publications per author. Together they contributed $4.30 \%$ (150) global publications share and $12.98 \%$ (3761) global citations share. Their detailed scientometric profile of top 15 most productive authors is presented in Table 7. On further analysis, it was observed that : (i) Six of top 15 authors registered their publications output above the group average of 10.0: D.Buonsensov (Italy) (15 papers), C.Calvo (Spain), X. Lu (China( and A. Villani (Italy)(12 papers each), A. Campana (Italy) and G.L. Marseglia (Italy)(11 papers each); and (ii) Four of top 15 authors registered their citation per paper and relative citation index above the group average (25.07 and 3.02) of all authors: X.Lu (China)( 103.83 and 12.49); A. Licari (Italy)( 40.11 and 4.83), G.L. Marseglia (Italy)(34.09 and 4.1) and D. Buonsenso (Italy)( 32.2 and 3.87).

\section{Medium of Research Communication}

All paperss on "Impact of COVID-19 on Children and Adolescents" appeared in 371 journals: 258 journals published in 1-5 papers each, 61 journals published 6-10 papers each, 29 journala published 11-20 papers each, 17 journals published 21-50 papers and 6 journals published 51-71 papers each. The top 15 most productive journals accounted for $20.286 \%$ share of global publications in journals.

JAMA Pediatrics was the topmost productive journal (with 71 papers) in reporting Indian research in the field of "Impact of COVID-19 on Children and Adolescents", followed by Pediatrics Infectious Disease Journal (60 papers), Acta Paediatrica International Journal of Pediatrics (58 papers), Frontiers in Pediatrics (55 papers), Journal of Pediatrics (52 papers), Pediatrics(51 papers), Pediatric Pulmonology (48 papers), etc, Pediatrics was the tomost most impact ful journal in terms of citation per paper (36.59)., followed by JAMA Pediatrics (19.49), Acta Paediatrica International Journal of Pediatrics (14.93), Journal of Pediatrics (12.46), Pediatrics Infectious Disease Journal (12.05), Archives of Disease in Childhood (7.30), Frontiers in Pediatrics (6.35), etc. (Table 8).

\section{High Cited Papers}

Of the total global output in "Impact of COVID-19 on Children and Adolescents" (3488 publications), only 52 (1.49\% share) accumulated 101 to 1167 citations per paper (cumulative total 13345 citations) since their publication during 2020-21, averaging to 256.63 citations per paper. The distribution of these 52 highly cited papers is skewed: Twenty seven papers registered citations in the range 101-194 per paper, 11 papers were in citation range 203-287, 9 papers in citation range 303-498, 4 papers in citation range 519-880 and 1 paper received 1167 citations. Of the 52 highly cited papers, 23 were published as articles, 10 as letters, 9 as reviews, 6 as notes, and 2 each as short surveys and editorials. Of the 52 highly cited papers, 8 resulted from contribution by single organizations per paper (non-collaborative papers) and 44 from two or more organizations per paper (32 national collaborative and 12 international collaborative papers). 


\begin{tabular}{|c|c|c|c|c|c|c|c|c|}
\hline S.No & Name of the Organization & TP & TC & CPP & $\mathrm{HI}$ & ICP & $\%$ ICP & $\mathrm{RCl}$ \\
\hline 1 & Harvard Medical School, USA & 80 & 1142 & 14.28 & 10 & 28 & 35.00 & 1.72 \\
\hline 2 & Huazhong University of Science and Technology, China & 67 & 2142 & 31.97 & 17 & 23 & 34.33 & 3.85 \\
\hline 3 & Tongji Medical College, China & 63 & 1255 & 19.92 & 16 & 20 & 31.75 & 2.40 \\
\hline 4 & Children's Hospital, Boston, USA & 61 & 997 & 16.34 & 10 & 24 & 39.34 & 1.97 \\
\hline 5 & Bambino Gesù Children's Hospital, Italy & 53 & 718 & 13.55 & 10 & 21 & 39.62 & 1.63 \\
\hline 6 & INSERM, France & 46 & 807 & 17.54 & 10 & 16 & 34.78 & 2.11 \\
\hline 7 & Hospital for Sick Children University of Toronto, Canada & 46 & 497 & 10.80 & 11 & 32 & 69.57 & 1.30 \\
\hline 8 & University of Toronto, Canada & 45 & 179 & 3.98 & 8 & 21 & 46.67 & 0.48 \\
\hline 9 & Sapienza University of Rome, Italy & 45 & 263 & 5.84 & 9 & 13 & 28.89 & 0.70 \\
\hline 10 & University of Melbourne, Australia & 43 & 718 & 16.70 & 7 & 30 & 69.77 & 2.01 \\
\hline 11 & University College London, U.K. & 41 & 589 & 14.37 & 10 & 24 & 58.54 & 1.73 \\
\hline 12 & ThE Childrens Hospital of Philadelphia, USA & 40 & 772 & 19.30 & 11 & 9 & 22.50 & 2.32 \\
\hline 13 & University of Milan, Italy & 39 & 266 & 6.82 & 8 & 7 & 17.95 & 0.82 \\
\hline 14 & Baylor College of Medicine, USA & 33 & 439 & 13.30 & 6 & 6 & 18.18 & 1.60 \\
\hline \multirow[t]{4}{*}{15} & University of British Columbia, Canada & 33 & 241 & 7.30 & 10 & 12 & 36.36 & 0.88 \\
\hline & Total of 15 organizations & 735 & 11025 & 15.00 & 10.2 & 286 & 38.91 & 1.81 \\
\hline & Global total & 3488 & 28972 & 8.31 & & & & \\
\hline & Share of top 15 organizations in global total & 21.07 & 38.05 & & & & & \\
\hline
\end{tabular}

TP=Total Papers; TC=Total Citations; CPP=Citations Per Paper; ICP=International Collaborative Papers; HI=h-Index; RCI=Relative Citation Index

\begin{tabular}{|c|c|c|c|}
\hline S.No & Name of the Organization & Number of Collaborative Linkages & TCL (NOO) \\
\hline 1 & Harvard Medical School, USA & 2(2), 3(1), 4(46), 6(1), 7(6), 8(3), 11(1), 12(5), 14(4) & $69(9)$ \\
\hline 2 & Huazhong University of Science and Technology, China & $1(2), 3(62), 4(2), 5(1), 11(4)$ & $71(5)$ \\
\hline 3 & Tongji Medical College, China & $1(1), 2(62), 5(1), 11(4)$ & $68(5)$ \\
\hline 4 & Children’s Hospital, Boston, USA & 1(46), 2(2), 6(2), 7(10), 8(4), 10(3), 12(8), 14(4) & $79(9)$ \\
\hline 5 & Bambino Gesù Children’s Hospital, Italy & $1(1), 2(1), 3(1), 6(2), 9(10), 10(2), 11(2), 13(5)$ & $24(8)$ \\
\hline 6 & INSERM, France & $1(1), 5(2)$, & $3(2)$ \\
\hline 7 & Hospital for Sick Children University of Toronto, Canada & $1(6), 4(10), 8(22), 11(3), 12(5), 14(2), 15(9)$ & $57(7)$ \\
\hline 8 & University of Toronto, Canada & 1(3), 4(4), 7(22), 11(1), 14(1), 15(10) & $41(6)$ \\
\hline 9 & Sapienza University of Rome, Italy & $5(10), 11(1), 13(1)$ & $12(3)$ \\
\hline 10 & University of Melbourne, Australia & $4(3), 5(2), 7(4), 11(5), 14(1)$ & $15(5)$ \\
\hline 11 & University College London, U.K. & 1(1), 2(4), 3(4), 5(2), 7(3), 8(1), 9(1), 10(5), 14(1) & 22(9) \\
\hline 12 & The Childrens Hospital of Philadelphia, USA & $1(5), 4(8), 7(5), 14(2)$ & $20(4)$ \\
\hline 13 & University of Milan, Italy & $5(5), 9(1)$ & $6(2)$ \\
\hline 14 & Baylor College of Medicine, USA & $1(4), 7(2), 8(1), 10(1), 11(1), 12(2), 14(4)$ & $15(7)$ \\
\hline 15 & University of British Columbia, Canada & $7(9), 8(10)$ & $19(2)$ \\
\hline
\end{tabular}

TCL=Total Collaborative Linkages; NOO=Number of organizations

Among the 52 highly cited papers, China partcipitated in the largest number of papers (22 papers), followed by USA (18 papers), Italy and U.K. (5 papers each), Taiwan (3 papers), Australia, Austria, France, Hong Kong, Spain and Sweden (2 papers each), Belgium, Bulgaria, Canada, Germany, Israel, Singapore, Slovenia and Switzerland (1 papers each). The 52 high cited papers involve 306 organizations and 562 authors. These 52 highly papers appeared across 36 journals, of which 5 papers each were published in New England Journal of Medicine and JAMA
Pediatrics, 3 papers each in JAMA-Journal of the American Medical Association and Lancet Child and Adolescent Health, 2 papers each in Acta Paediatrica, Circulation, The Lancet and Pediatrics, 1 paper each in 28 other journals.

\section{SUMMARY AND CONCLUSION}

Using quantitative and qualitative indicators, the present paper provides a bibliometric assessment of global literature (3488 records) on "Impact 


\begin{tabular}{|c|c|c|c|c|c|c|c|c|c|}
\hline S.No & $\begin{array}{c}\text { Name of the } \\
\text { Author }\end{array}$ & Affiliation of the Author & TP & TC & CPP & $\mathrm{HI}$ & ICP & $\% \mathrm{ICP}$ & $\mathrm{RCl}$ \\
\hline 2 & C.Calvo & La Paz University Hospital, Spain & 12 & 218 & 18.17 & 4 & 2 & 16.67 & 2.19 \\
\hline 3 & X.Lu & Huazhong University of Science and Technology, China & 12 & 1246 & 103.83 & 7 & 3 & 25.00 & 12.49 \\
\hline 4 & A.Villani & Bambino Gesù Children's Hospital, Italy & 12 & 173 & 14.42 & 5 & 1 & 8.33 & 1.73 \\
\hline 6 & G.L.Marseglia & Policlinico San Matteo, Italy & 11 & 375 & 34.09 & 5 & 0 & 0.00 & 4.10 \\
\hline 7 & L.Provenzi & University of Pavia, Italy & 10 & 16 & 1.60 & 3 & 0 & 0.00 & 0.19 \\
\hline 8 & R.Borgatti & University of Pavia, Italy & 9 & 15 & 1.67 & 3 & 0 & 0.00 & 0.20 \\
\hline 9 & E.H. Choi & Seoul National University, South Korea & 9 & 113 & 12.56 & 4 & 1 & 11.11 & 1.51 \\
\hline 13 & M.Ceyhan & Ankara Numune Education and Research Hospital, Turkey & 8 & 11 & 1.38 & 1 & 0 & 0.00 & 0.17 \\
\hline 14 & S.Esposito & University of Parma, Italy & 8 & 109 & 13.63 & 3 & 0 & 0.00 & 1.64 \\
\hline \multirow[t]{4}{*}{15} & K.G.Friedman & Harvard Medical School, USA & 8 & 127 & 15.88 & 4 & 3 & 37.50 & 1.91 \\
\hline & & Total of top 15 authors & 150 & 3761 & 25.07 & 4 & 25 & 16.67 & 3.02 \\
\hline & & Global total & 3488 & 28972 & 8.31 & & & & \\
\hline & & Share of top 15 authors in global total & 4.30 & 12.98 & & & & & \\
\hline
\end{tabular}

TP=Total Papers; TC=Total Citations; CPP=Citations Per Paper; ICP=International Collaborative Papers; HI= $h$-Index; RCI=Relative Citation Index

\begin{tabular}{|c|c|c|c|c|}
\hline S.No & Name of the Journal & TP & TC & CPP \\
\hline 1 & JAMA Pediatrics & 71 & 1384 & 19.49 \\
\hline 2 & Pediatrics Infectious Disease Journal & 60 & 723 & 12.05 \\
\hline 3 & $\begin{array}{c}\text { Acta Paediatrica International Journal of } \\
\text { Pediatrics }\end{array}$ & 58 & 866 & 14.93 \\
\hline 4 & Frontiers in Pediatrics & 55 & 349 & 6.35 \\
\hline 5 & Journal of Pediatrics & 52 & 648 & 12.46 \\
\hline 6 & Pediatrics & 51 & 1866 & 36.59 \\
\hline 7 & Pediatric Pulmonology & 48 & 285 & 5.94 \\
\hline 8 & $\begin{array}{l}\text { International Journal of Environmental } \\
\text { Research and Public Health }\end{array}$ & 45 & 85 & 1.89 \\
\hline 9 & Journal of Adolescent Health & 45 & 273 & 6.07 \\
\hline 10 & Indian Pediatrics & 44 & 225 & 5.11 \\
\hline 11 & Pediatric Blood and Cancer & 42 & 240 & 5.71 \\
\hline 12 & Child Abuse and Neglect & 34 & 94 & 2.76 \\
\hline 13 & Journal of Pediatrics and Child Health & 34 & 83 & 2.44 \\
\hline 14 & Archives of Disease in Childhood & 33 & 241 & 7.30 \\
\hline \multirow[t]{4}{*}{15} & Indian Journal of Paediatrics & 33 & 154 & 4.67 \\
\hline & Total of 15 journals & 705 & 7516 & 10.66 \\
\hline & Global total & 3476 & & \\
\hline & Share of top 15 journals in gobal total & 20.28 & & \\
\hline
\end{tabular}

of COVID-19 on Children and Adolescents" based on indexed publications in Scopus database covering 2020-21 period.. The global publications on this theme averaged 8.31 citations per paper. Only $1.49 \%$ share (52 papers) of the global publications on this subject received funding support from various national and international research agencies and averaged 256.63 citations per paper.

Although 145 countries participitated in global research on "Impact of COVID-19 on Children and Adolescents", but the combined output of top 10 most productive countries alone accounts for $85.21 \%$ share and more than $100 \%$ share of global publications and citations output. On one hand, USA, U.K., Italy and China contributed the global publication share of $26.98 \%, 11.41 \%$ and $10.92 \%$ respectively, but on the other hand China (3.16), U.K (1.28), USA(1.27) and France (1.22) registered comparatively higher relative citation index among top 10 countries. The share of international collaborative papers in global output varied from $13.60 \%$ to $61.29 \%$, with average value as $33.48 \%$ during $2020-21$. Top 10 countries have strong collaborative linkages among themselves with USA-Canada having the strongest collaborative linkages (63 linkages), followed by USA - U.K. (59 linkages), USA-Canada (41 linkages), U.K. - Italy (37 linkages), USA-China (37 linkages), usa-Italy (34 linkages), U.K.-Spain (31 linkages), etc

Medicine contributed the largest share (83.89\%) to gobal publications output on on 'Impact of COVID-19 on Children and Adolescents', followed by Psychology (10.24\%), Social sciences (7.68\%), and other five subjects contributing less than $5.0 \%$ (from $1.58 \%$ to $4.90 \%$ ). The major focus of global research on "Impact of COVID-19 on Cildren and Adolescents" has been on mental health related disorders (51.55\%), followed by respiratory related disorders $(17.06 \%)$ and the rest on extrapulmonary manifestions of COVID-19 disease.

The 412 organizations and 661 authors participated in global research on this theme, with the top 15 most productive organizations and authors 
contributing $21.07 \%$ and $4.30 \%$ global publications share and $38.05 \%$ and $12.98 \%$ global citations share. Harvard Medical School, USA (80 papers), Huazhong University of Science and Technology, China (67 papers), Tongji Medical College, China (63 papers), Children's Hospital, Boston, USA (61 papers) and IRCCS Ospedale Pediatrico Bambino Gesu, Italy (53 papers) were the most productive global organizations and Huazhong University of Science and Technology, China (31.97 and 3.85), Tongji Medical College, China (19.92 and 2.40), Childrens Hospital of Philadelphia, USA (19.30 and 2.32), INSERM, France (17.54 and 2.11), University of Melbourne, Australia (16.70 and 2.01) and Children's Hospital, Boston, USA (16.34 and 1.97) were the most impactful organizations in terms of citations per paper and relative citation index. The top 15 organizations have strong collaborative linkages among themselves, with Huazhong University oF Science and Technology, China and Tongji Medical College, China have the strongest collaborative linkages (62) followed by Harvard Medical School, USA and Children's Hospital, Boston, USA (46 linkages), etc.

D. Buonsensov (15 papers), C. Calvo, X. Lu and A. Villani (12 papers each), A. Campana and G.L. Marseglia(11 papers each) were the most productive authors and X.Lu (103.83 and 12.49), A. Licari ( 40.11 and 4.83), G.L. Marseglia (34.09 and 4.1) and D. Buonsenso ( 32.2 and 3.87) were the most impactful authors.

JAMA Pediatrics (71 papers), Pediatrics Infectious Disease Journal (60 papers), Acta Paediatrica International Journal of Pediatrics (58 papers), Frontiers in Pediatrics (55 papers), Journal of Pediatrics (52 papers), Pediatrics (51 papers) and Pediatric Pulmonology (48 papers) were the leading most productive journals in reporting global research in the field of "Impact of COVID-19 on Children and Adolescents". Pediatrics (36.59), JAMA Pediatrics (19.49), Acta Paediatrica International Journal of Pediatrics (14.93), Journal of Pediatrics (12.46), Pediatrics Infectious Disease Journal (12.05), Archives of Disease in Childhood (7.30) and Frontiers in Pediatrics (6.35) were the leading journal in terms of citation impact per paper.

The 52 (1.49\%) out of 3488 global publications on "Impact of COVID-19 on Children and Adolescents" registered 101 to 1167 citations per paper and they together received 13345 citations, averaging to 256.63 citations per paper. These 52 publications are assumed as highly cited and involve the 16 countries, 306 organizations, 562 authors and published in 36 journals.

\section{CONFLICT OF INTEREST}

The authors declare no conflict of interest.

\section{REFERENCES}

1. Mohan BS, Vinod N. COVID-19: An Insight into SARS-CoV2 Pandemic Originated at Wuhan City in Hubei Province of China. J Infect Dis Epidemiol. 2020;6(4):146. doi: 10.23937/2474-3658/1510146.

2. WHO. Coronavirus (COVID-19) dashboard [cited 16.5.2021]. Available from: https://covid19. who.int/?gclid=EAlalQobChMIx5v1q_HM8AIVxmSLCh3XuwtMEAAYASABEgKsI_D_BwE.

3. Singh S, Roy D, Sinha K, Parveen S, Sharma G, Joshi G. Impact of COVID-19 and lockdown on mental health of children and adolescents: A narrative review with recommendations. Psychiatry Res. 2020;293:113429. doi: 10.1016/j.psychres.2020.113429. PMID 32882598.

4. Deville JG. Eunkyung Song andChristopher P Ouellette. COVID-19: clinical manifestations and diagnosis in children https://www.uptodate.com/contents/ covid-19-clinical-manifestations-and-diagnosis-in-children.

5. Götzinger F Santiago-García B, Noguera-Julián A Lanaspa M, Lancella L, Calò Carducci Fl, Gabrovska N, Velizarova S, Prunk P, Osterman V, Krivec U, Lo Vecchio A, Shingadia D, Soriano-Arandes A, Melendo S, Lanari M, Pierantoni L, Wagner N, L'Huillier AG, Heininger U, Ritz N, Bandi S, Krajcar N, Roglic S, Santos M. Christiaens C, Creuven M, Buonsenso D, Welch SB, Bogyi M, Brinkmann F Tebruegge M, ptbnet COVID-19 Study Group. COVID-19 in children and adolescents in Europe: a multinational, multicentre cohort study. Lancet Child Adolesc Health. September 1 2020;4(9):653-61. doi: 10.1016/S2352-4642(20)30177-2, PMID 32593339.

6. Shah K, Mann S, Singh R, Bangar R, Kulkarni R. Impact of COVID-19 on the mental health of children and adolescents. Cureus. August 26 2020;12(8):e10051. doi: 10.7759/cureus.10051, PMID 32999774.

7. OECD policy responses to coronavirus (COVID-19). Combatting COVID-19's effect on children; Updated August 112020 [cited 17.3.2021]. Available from: https://www.oecd.org/coronavirus/policy-responses/combatting-covid-19-seffect-on-children-2e1f3b2f/.

8. Brosnahan SB, Jonkman AH, Kugler MC, Munger JS, Kaufman DA. COVID-19 and Respiratory System Disorders: Current Knowledge, Future Clinical and Translational Research Questions. Arterioscler Thromb Vasc Biol. 2020;40(11):2586-97. doi: 10.1161/ATVBAHA.120.314515, PMID 32960072.

9. Pedro A. Pousa. SC, Mendonça:Tamires, Eduardo A,. Oliveira, Ana and Cristina Simões-e-Silva. Extrapulmonary manifestations of COVID-19 in children: A comprehensive review and pathophysiological considerations. Jornal de Pediatria, 2021, 97(2), 116-139, https://doi.org/10.1016/j.jped.2020.08.007.

10. Deng Z, Chen J, Wang T. Bibliometric and visualization analysis of human coronaviruses: prospects and implications for COVID-19 research. Front Cell Infect Microbiol. 2020;10. Published:581404. doi: 10.3389/fcimb.2020.581404.

11. Monzani A, Tagliaferri F, Bellone S, Genoni G, Rabbone I. The fast-motion research process about COVID-19 in children: A bibliometric review. JMIR pediatrics and parenting. 11.05. Vol. 24791; 2021 (in press).

12. Grover, Sandeep, Gupta BM, Mamdapur, Modin G. Impact of COVID-19 on Mental Health of Children's and Adolescents: A bibliometric assessment of global publications. (Submitted for publications in Asian Pacific Psychiatry).

Cite this article : Gupta BM, Surulinathi M, Mamdapur GMN, Bansal J, Bansal M. Impact of COVID-19 on Children and Adults: A Bibliometric Assessment of Global Publications. Int J Med Public Health. 2021;11(3):139-45. 